\title{
Recent and Prospective Developments in International Trade and Finance
}

\author{
HANS H. HELBLING
}

REVIEW of U.S. economic developments in 1973 generally tends to focus on some of the "negative" domestic events, such as accelerating inflation, slowdowns in production and employment growth, and shortages of many necessary inputs to the production process. However, so often overlooked is this country's performance in the intermational arena. For the first time in the past three years, our intemational accounts registered surpluses or greatly reduced deficits.

This reversal resulted partly from policy actions initiated by the United States and other industrial countries in August and December 1971. These actions were intended to faclitate adjustments in the then existing balance-of-payments disequilibrim. The expected adjustment began to take hold in mid-1972, but the speed and magnitude of the adjustment in 1973 was affected by "special" factors prevailing that year, such as a world-wide economic boom and poor harvests in many parts of the world.

Although world-wide agricultural developments are expected to improve and many economies are beginning to show signs of slowing, 1974 is likely to be affected by another set of "special" circumstances though not in the same direction. In particular, a great deal of uncertainty exists resulting from the combined infthence of 1) continued U.S. dependence on imported oil, 2) uncertainty about crude oil prices in world markets, and 3) varying rates of growth in economic activity throughout the world,

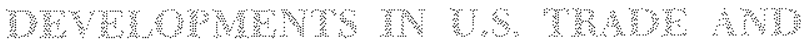

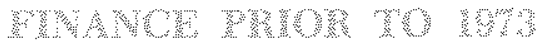

Economic relationships between the United States and the rest of the world have undergone an evolution during the post-Wonld War II era. Reffecting this, the U.S. external accounts swung from trade supluses in the period from the late 1940 s to the mid-1960s, to

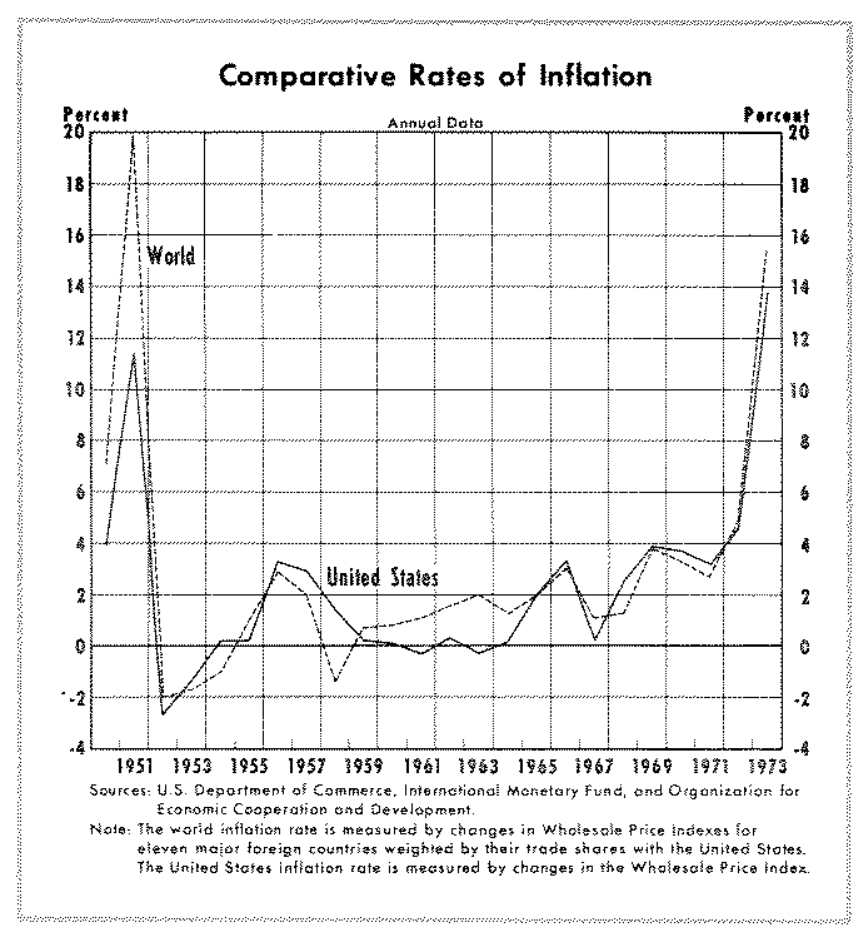

trade deficits in 1971 and 1972, and finally, in 1973, back to a surplus again. At the same time, the U.S. dollar changed from the world's strongest currency to one which was subjected to massive speculation in foreign exchange markets.

As intationary pressures developed in the United States in 1965 (see chart entitled "Comparative Rates of Inflation"), the trade surplus began to diminish. Under the prevailing regime of fixed exchange rates, prices in the U.S. increased relative to foreign price levels, and the demand for imports accelerated. The relative price decrease of forcign goods in the United States and relative price increases of U.S. goods in foreign markets were conducive to a sharp increase in imports as a share of U.S. gross national product and to the continued decline in the U.S. share of world 


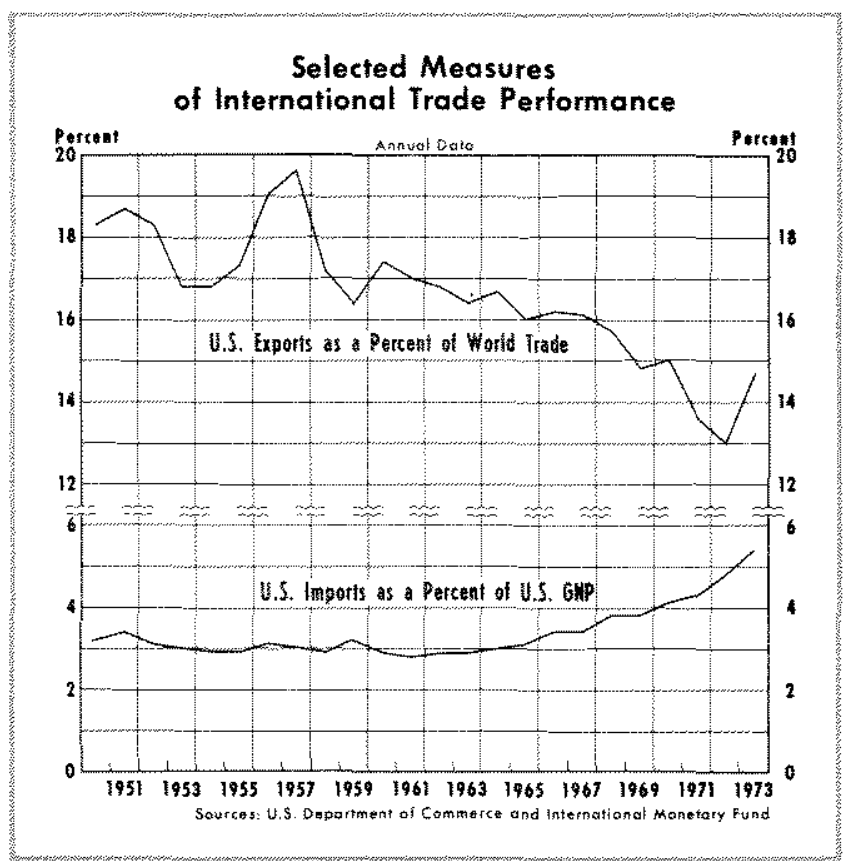

exports ( see chart entitled "Selected Measures of International Trade Performance"). As private and government capital continued to flow out and as the trade surplus narrowed, the basic balance deficit increased. ${ }^{1}$

In 1971 it became obvious that the disequilibrium in the U.S. basic balance was unsustainable. As a result, confidence in the maintenance of the international price of the dollar eroded to such an extent that the foreign demand for dollars as an international currency declined significantly. Increasing deficits in both the liquidity and the official settlements balances precipitated an international monetary crisis in the spring of 1971.2 In August 1971 the United States responded to this crisis by suspending the convertibility of officially held foreign dollars into gold, imposing a 10 percent surcharge on merchandise shipped to this country, and letting it be known to their trading part-

${ }_{1}^{1}$ In addition to goods, services, and milateral transfers, the basic balance includes long-term capital movements. Ideally, this balance should be in equilibrium over time such that outflows of long-term capital are offset by inflows resulting from a trade surplus (or vice-versa). If a temporary imbalance exists, the teficit (surplus) could be financed by temporary short-term capital inflows (outfows). Since 1949 the U.S. basic balance, however, has been persistently in deficit, which has given xise to the accumulation of foreign owned dollar balances. As the basic balance deficit increased in recent years, the accumulation of actual dollar balances by foreigners apparently exceeded desired dollar balances.

2The liquidity balance, in addition to the basic balance, includes non-liquid short-term private capital and errors and omissions. This balance is a measure of potential short-term claims of foreigners, both private and official against the U.S. dollar. The official settlements balance adds changes in liquid private capital to the liqudity balance. Thus, if private forefgners sell short-term dollar claims to their central bank, the official settlements deficit would exceed the liquidity deficit by the amount of the sale.

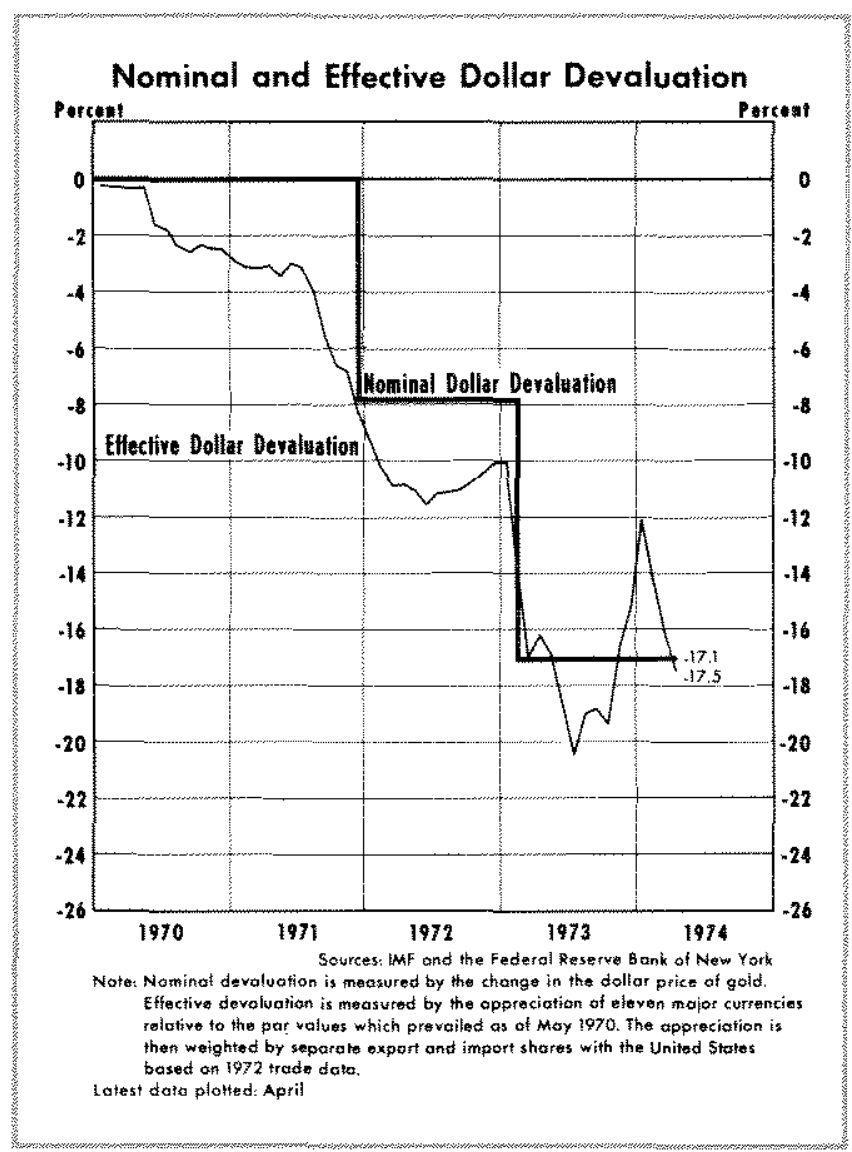

ners that changes in the international competitive position of the United States were necessary. Specifically, there was an expressed desire for equilibrium in the basic balance. International negotiations and departures from a fixed exchange rate resulted in the depreciation of the dollar relative to other currencies (see chart entitled "Nominal and Effective Dollar Devaluation")..$^{3}$

It seems that intemational trade and financial transactions between the United States and the rest of the world have responded to these actions. Beginning in mid-1972, U.S. imports from foreign countries in-

3 At the December 1971 Smithsonian Conference, new exchange rates were negotiated and the United States lifted the surcharge on imports. The permissible range of exchange rate flexibility was also widened from 1.0 percent to 2.25 percent on each side of the par value. The U.S. received commitments from its major trading partners concerting a reduction of trade restrictions. However, this did not result in a calm and stable international environment, and speculation against the dollar continued. The following maior events transpired since December 1971: In May of 1972 the original Common Market countries, the United Kingdom, and Denmark jointly agreed to a narrow range of exchange rate fiexibility of $1 \frac{1 / 8}{8}$ percent among thenselves while maintaining the 2,25 percent intervention band on either side of the par value vis-a-vis all other currencies. In June, due to turmoil in exchange markets, the United Kingdom and Denmark withdrew from this arrangement and permitted their currencies to float. 
areased at a lower rate, while U.S. exponts to foreign countries increased at a higher rate than in 1971. In early 1973 the level of U.S. exports exceeded the level of $\mathrm{U}_{+} \mathrm{S}$. imports, and a trade balance surplus of $\$ 0.7$ billion was realized for the entire year.

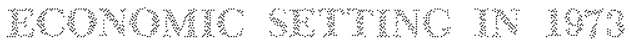

The new set of negotiated exchange rates which had been in effect throughout 1972 apparently did not restore complete confidence in the international financial system. During early 1973 interuational capital movements increased to such an extent that foreign central banks were either unwilling or unable to support the new exchange rates. First, Italy and Switzerland stopped supporting official exchange rates. This had the effect of accelerating the capital inflows into Japan and Germany."

Finally, on February 9, foreign exchange markets were closed. Following consultations and negotiations among several countries, the United States announced on February 12 its decision to devalue the dollar with respect to gold by an additional 10 percent. The Japanese Covernment also decided to let the exchange rate for the yen be determined primarily by market forces. When Japanese exchange markets reopened on February 14, the yen-dollar exchange rate rose about 18 percent above the previously fixed rate.

These actions, however, still failed to convince foreign holders of dollars that equilibrium exchange rates had been established, and massive conversion of dollars into foreign currencies continued. On March 2 the official foreign exchange markets were closed again and were not reopened until March 19, 1973. During this period several European countries (Belgium, Denmark, France, Germany, Netherlands, Norway, and Sweden) decided to abandon the fixed exchange rates between their respective currencies and the dollar in favor of floating rates; however, due to the strong trade wes between these countries, they decided to maintain fixed exchange rates relative to each other.

In this environment of flexible exchange rates, the international price of the dollar continued to decline until early July, At this time various central banks, including the Federal Reserve System, indicated their willingness to intervene in foreign exchange markets.

4U.S. liabilities to foreign central banks increased by about $\$ 9.0$ billion between December 1973 and March 1974 . Between February 1 and February 9, the German Central Bank alone bought $\$ 6$ billion.

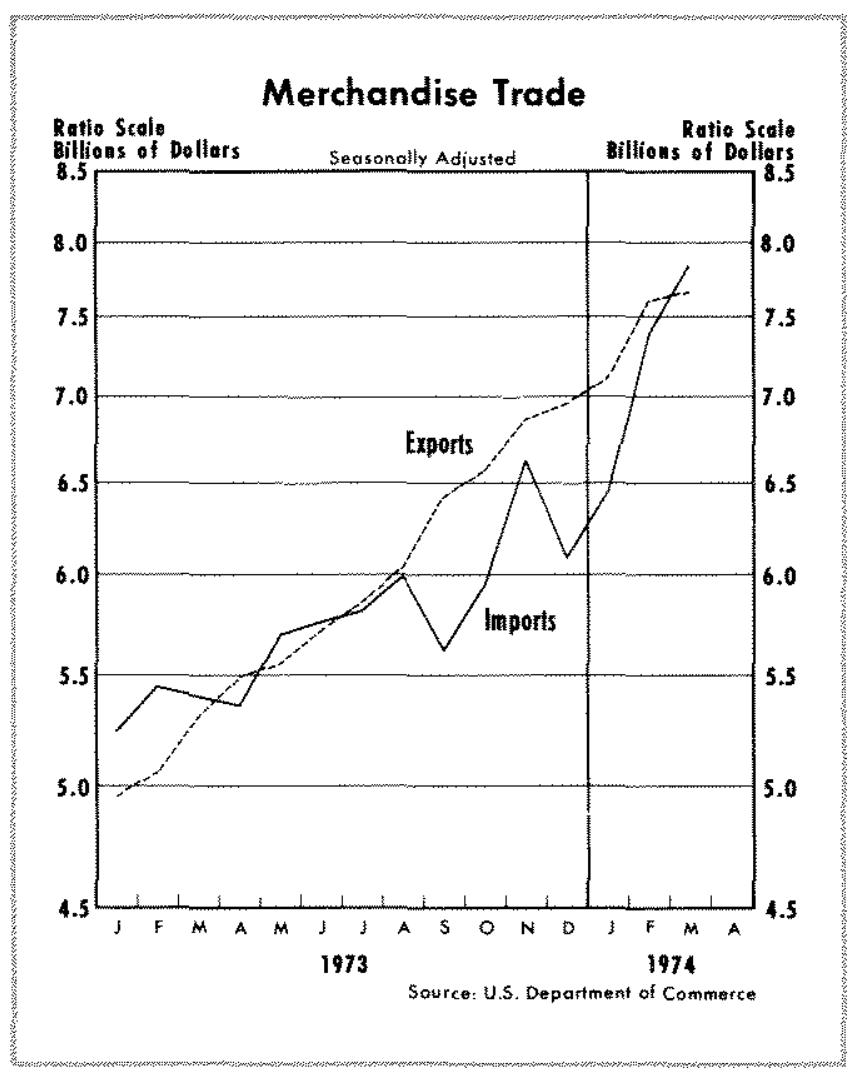

Although the aotual intervention was minimal in amount, the international price of the dollar stabilized.

During August the dollar exohange rate began to increase, probably prompted by the trade surplus which had developed during the previous month. Late in October the rate increased sharply, apparently reflecting contiuued and increasing U.S. trade surpluses as well as anticipations that the Middle-East oll embargo would affect economic conditions more adversely abroad than in the United States. In spite of these increases in the dollar exchange rate diming the latter part of 1973, the average international price of the dollar for 1973 was still below that of 1972. As a result, the competitiveness of U.S. goods in world markets continued to improve.

In addition to the dollar's lower international price, there were other influences which contributed to the improved competitive position. During 1973 most major industrial countries were in the upswing phase of a business cycle which began in 1971; however, the U.S. cyclioal expansion began a year earlier and the peak was reached in the first quarter of 1973 (see chart entitled "Comparative Rates of Change in Real Output"). Also, the rate of inflation was greater in most European countries and Japan. Both of these factors openated to increase foreign demand for U.S. exports relative to U.S. demand for imports. 


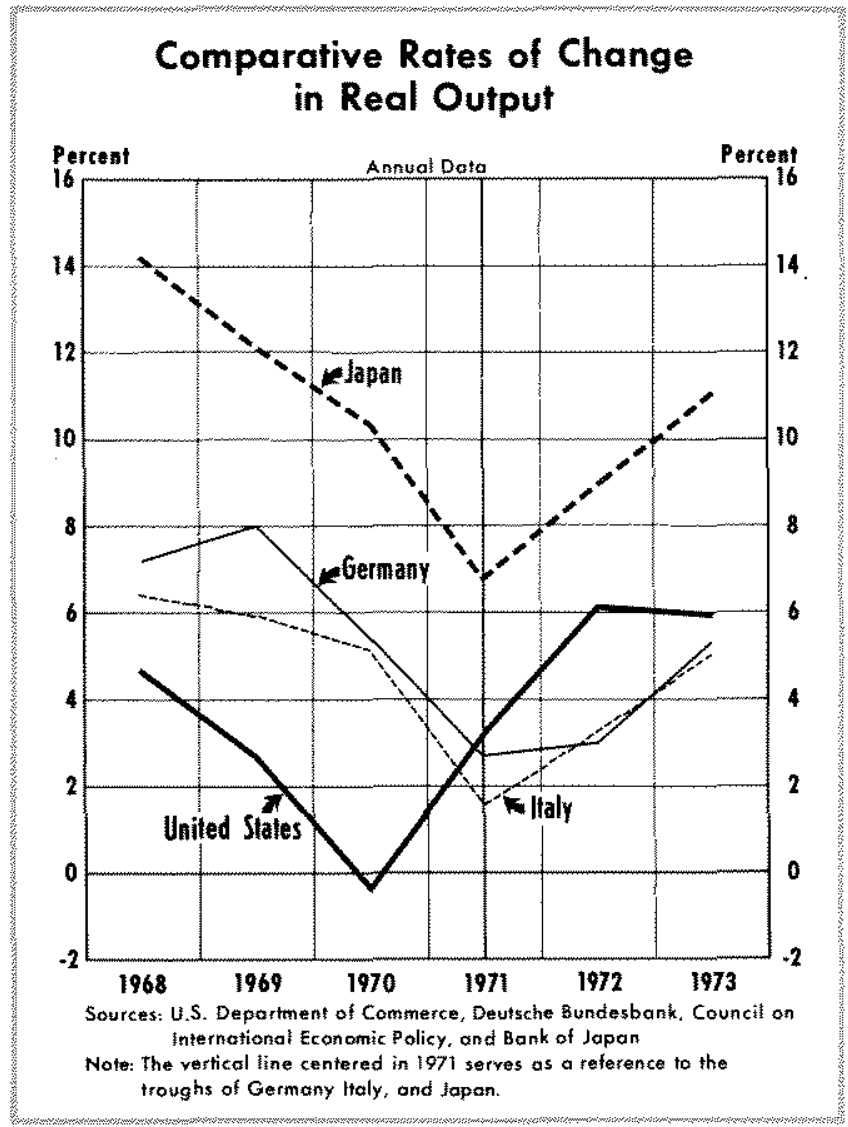

Poor harvests in many parts of the world contributed to a large increase in the demand for U.S. agricultural goods. At the same time, price controls on some farm products tended to restrict agricultural output in the United States. The combination of these two influences contributed to sharply rising prices for agricultural exports. On the import side, however, the quantity of domestically-produced crude oil continued to decline and U.S. oil imports increased in order to make up the difference between domestic production and desired domestic consumption.

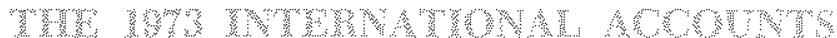

As a result of these events, the U.S. trade balance, generally considered an indicator of the U.S. competitive position in international markets, was in surplus by $\$ 0.7$ billion in 1973 . This followed two years of deficits amounting to $\$ 2.7$ billion in 1971 and $\$ 6.9$ billion in 1972. On balance, U.S. exports in 1973 increased by 44 percent over 1972. After adjusting for higher prices, exports rose by 23 percent. Imports, on the other hand, increased by only 5 percent in real terms over 1972. ${ }^{5}$ The goods and services balance and

ธThese percentages are derived from value and quantity indexes representing export and import totals for 1972 and 1973 .

Page 18 the current account balance in 1973 registered surpluses amounting to $\$ 6.9$ billion and $\$ 3$ billion, respectively.

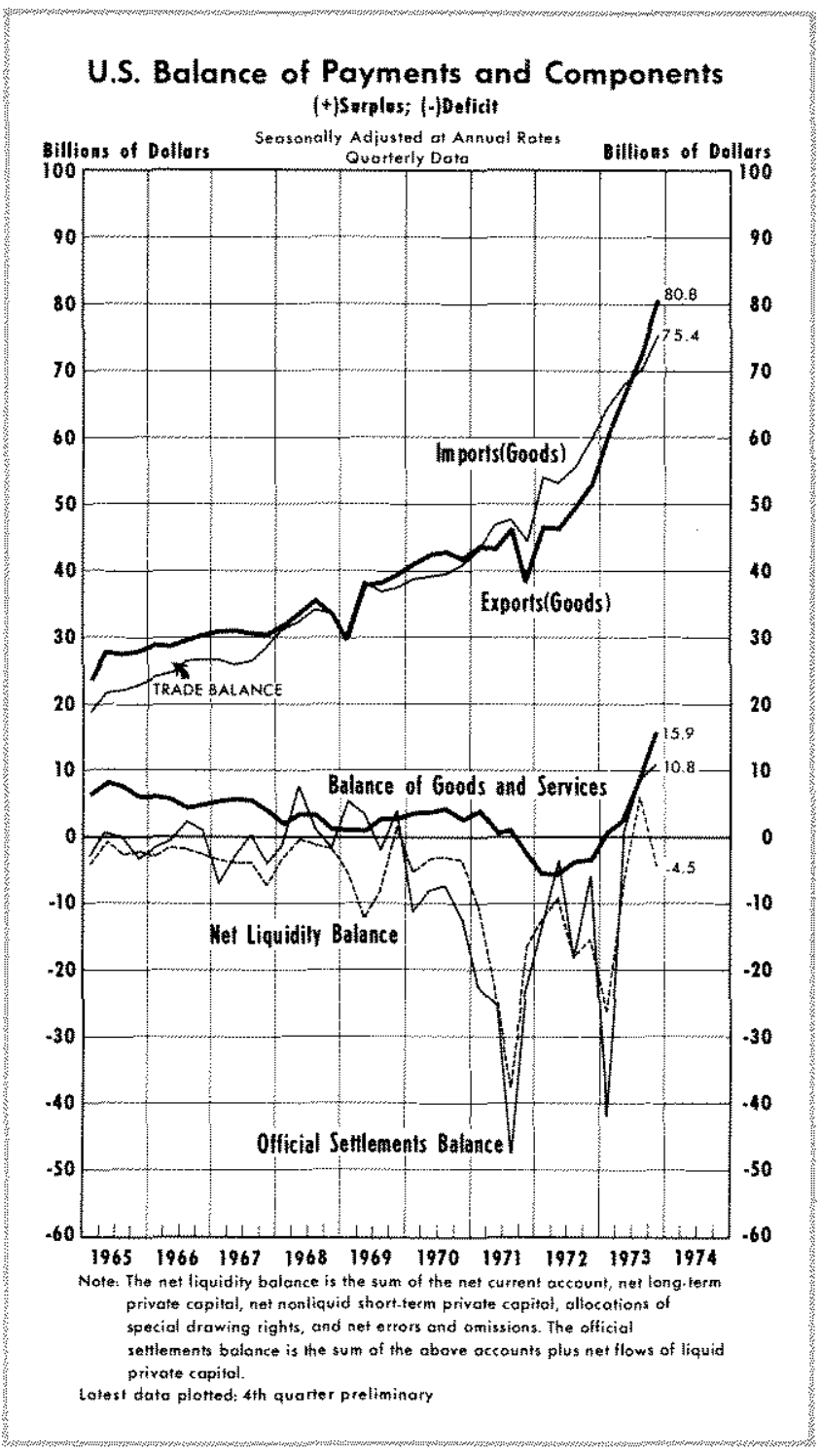

The U.S. basic balance (current account plus longterm capital), which is considered an indicator of underlying, or long-term, trends in the U.S. international economic position, was also in surplus by $\$ 1,2$ billion. This balance has been persistently in deficit since 1949 , reaching $\$ 9.8$ billion in 1972 .

The deficits in both the net liquidity and the official settlements balances ( $\$ 7.8$ and $\$ 5.3$ billion, respectively), were significantly smaller than in 1971 and 1972 (see the accompanying chart entitled "U.S. Balance of Payments and Components" and Table I). Had it not been for large speculative dollar outflows over the course of a few days in early 1973, even these balances might have been in, or near, surplus.

Page 18 


\section{Toblo 1}

U. S. BALANCE OF PAYMENTS, 1973 (1n Bilions of Dollars]

1) Merchandise Trode

1. Exports :

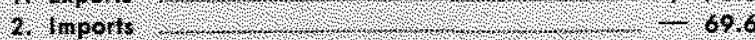

Mertiondts 7 todo Balonce

11. Services:

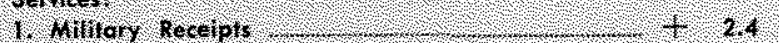

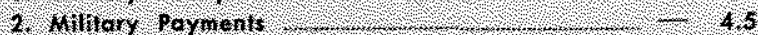

3. Treome on U S. Investments Abrood.

4. royments tor foreign Invertments in U S.

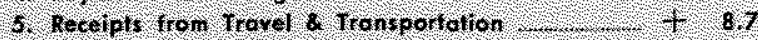

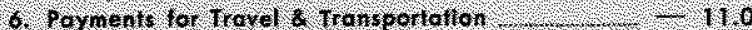

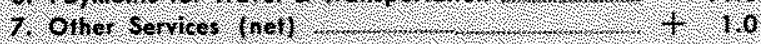

Balonte on Servites

coods ond Sorrices bolonke

11. tronster payments:

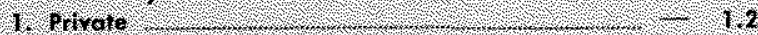

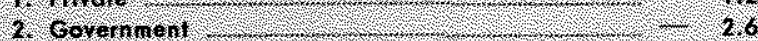

Bolance on Trantor loynonts.

Curront Aleount Bolance

N. torig wern Capitch:

1. Direct hrestnent Receiplt :

2. bired investment poyment 4 .

3. rortrolio Investment recetpls.

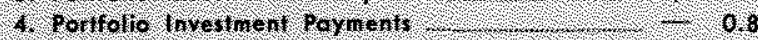

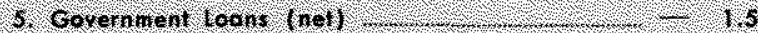

6. Oher long tern trell.

Balante on long toin Capito

Bosic Balance

1. stortitern pivale Capial:

1. Nonticuid hiobitite : 5 :

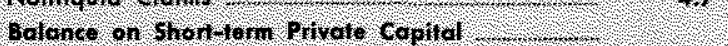

V1. Miscellaneovis:

1. Allocotion of Special Drowihg Rights (SDA).

2. Eriors and Omkitons.

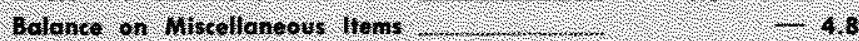

Net lquidit, Balones:

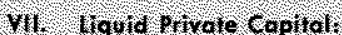

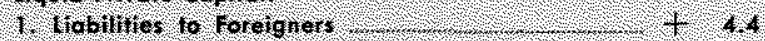

2. Goins on foreignets.

Balcince on liquid Privale copilal

\section{oriciol sertibuenth balonce. \\ (1)}

The Offird Sertlementi Balonce is finatced by Changes in

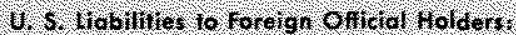

1. Nauid Iabillie.

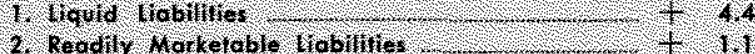

3. Spetial liablitios :

Balanee on Labilities to foretgn Officid Holders.

U. S. Tereno Awsts:

1. Gold : 2 (2:? 0.0

2. Sperior browitig kights.

3. Converible currencies?

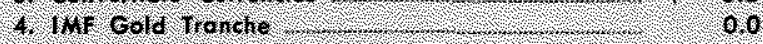

Balonce on Reserve Assets

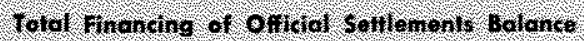

401

4.5 .3

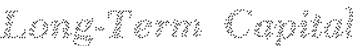

Net outtlows of long-term capital (portfolio and direct investment) in 1973 amounted to $\$ 1.8$ billion. In 1971 and 1972 these outflows amounted to $\$ 6.7$ billion and $\$ 1.5$ billion, respectively. The small net change over 1972 oceurred mainly in private long-term capital transactions. Direct investment expenditures by U.S. corporations abroad resulted in an outflow of $\$ 4.9$ billion in 1973 , compared to $\$ 3.4$ billion in 1972 . An outflow of $\$ 2$ billion, which occurred during the first quarter, may have been in anticipation of the February dollar devaluation. Direct investment expenditures in the United States on the part of foreign corporations (longterm capital inflows) increased sharply to $\$ 2.1$ billion, compared to $\$ 0.2$ billion in 1972 . While U.S. purchases of foreign securities increased to $\$ 0.8$ billion in 1973 , compared to $\$ 0.6$ billion in 1972 , foreign purchases of U.S. securities declined to $\$ 3.2$ billion, compared to $\$ 3.7$ billion in 1972.

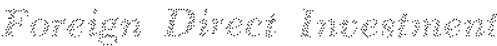

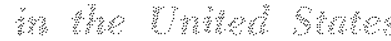

A significant change with respect to long-term capital transactions during 1973 was the increase in foreign direct investments in the United States. It is difficult to determine, however, to what extent this was due to the reduction in the international price of the dollar. In general, one would expect investment decisions to be based on rate-of-return considerations. It seems that these considerations tilted in favor of investing in the United States.

A number of factors, not all mutually exclusive, may have

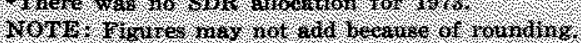




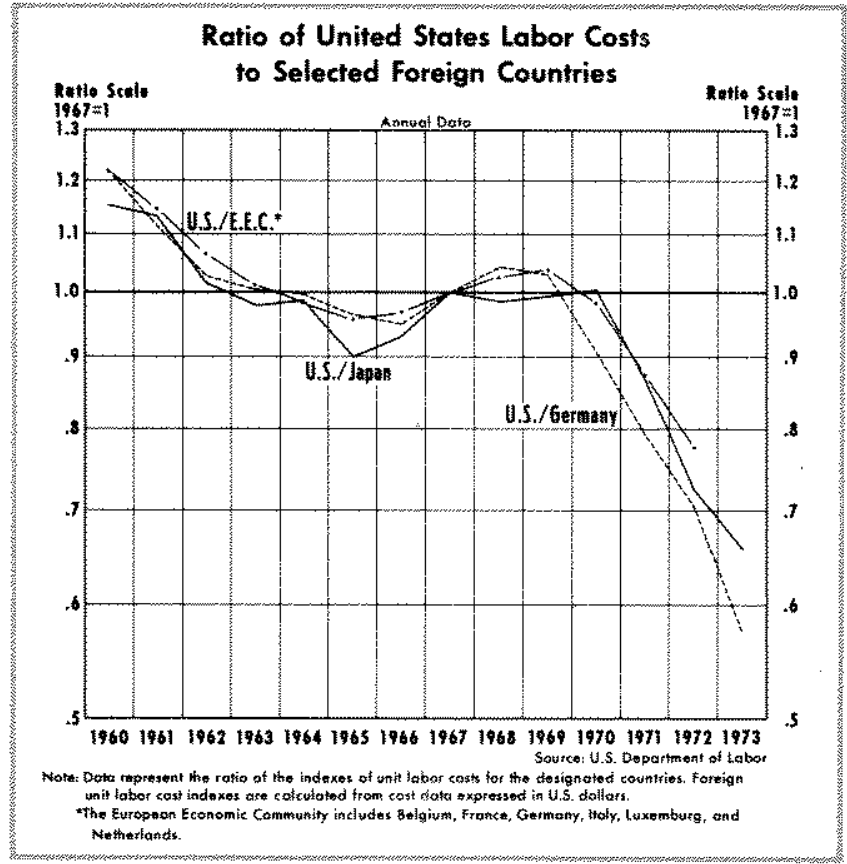

influenced this investment development: 1) production costs abroad rose faster than in the United States over a number of years (see chart entitled "Ratio of United States Labor Costs to Selected Foreign Countries"); 2) certain countries (Germany, Japan) experienced labor shortages; 3) as foreign corporations grew in size they may have decided to diversify intemationally as a hedge against domestic uncertainty and to improve profitability; 4) an increasing U.S. market share of many foreign firms may have made it more profitable for them to service the U.S. market from plants located within this market, rather than by producing abroad and shipping to the United States.

While the above factors were probably important elements in the formation of investment decisions by foreign corporations, it is not likely that these influences materialized suddenly in 1973. It is more probable that the increase in foreign investment expenditures in the United States was triggered by the reduction in the international price of the dollar. This depreciation reduced the probability of further dem preciation and the resulting capital losses which could be sustained by foreign investors.

\section{syon}

The net oufflow of short-term capital (nonliquid private short-term capital, errors and omissions, and liquid private capital $)^{6}$ increased during 1973 to $\$ 6.5$

Non-liquid short-term private capital refers to capital inflows or outhows (liabilities or claims) with maturities of one year or less that are not readily transferable, such as trade financ- billion, compared to $\$ 0.5$ billion in 1972 . However, they remained well below the levels of 1970 and 1971 . The large 1973 outflows of short-term capital were concentrated in the first quarter and were influenced by anticipations of capital gain by switching out of dollars into foreign currencies under the fixed exchange rate system that existed during this period.

After the first quarter of 1973 , the incentives for capital gains in foreign currencies were reduced by decisions of European countries and Japan to stop pegging their exchange rates. During the second quarter, for example, the international price of the dollar was still declining, but short-term private capital outflows ceased and a $\$ 1$ billion inflow (including errors and emissions) was recorded. During the third quarter there was a short-term capital outflow of $\$ 0.4$ billion. Reflecting the uncertainties associated with the oil embargo, there was an inflow of $\$ 2.5$ billion in the fourth quarter.

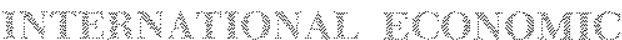

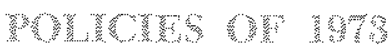

The most significant international development during 1973 was the decision of many governments to institute flexible exchange rates. The specific reasons for resorting to floating exchange rates differed from country to country, but in each case it was a pragmatic solution motivated by national self-interest.

For example, in the case of Japan and Switzerland, as well as the members of the jointly floating European currency block, floating resulted in an increase in the international prices of these currencies. If the central banks of these countries had intervened in exchange markets in order to maintain fixed exchange rates, they would have had to issue domestic currency as they bought foreign currency. This would have tended to expand their domestic money stocks, which in turn, would have intensified their inflationary pressures.

In the case of the United Kingdom and Italy, floating of the pound and the lira resulted in a reduction in the international prices of these currencies. If the central banks of these countries had tried to maintain the previously fixed exchange rates, they would have had to sell other currencies and reduce their stocks of international reserves. This would have tended to contract their domestic money stocks resulting in deflationary consequences.

ing and cash items in the process of collection. Errors and omissions is an adjustment entry for statistical discrepancies and includes largely short-term capital outflows not captured by the regular reporting channels. 


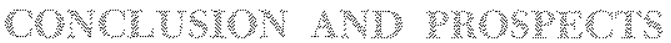 row}

Throughout 1973 it became increasingly apparent that the international monetary system had evolved away from fixed exchange rates to a new, yet undetermined, payments mechanism. For many countries, however, experience with flexible exchange rates may strongly influence the future international monetary system.

At one time, fixed exchange rates were deemed an absolute necessity for a smoothly functioning international monetary system. However, as demonstrated last year, many countries would rather permit the international prices of their currencies to adjust to market forces than to force the necessary adjustment onto the domestic sector of their economies. As far as the United States is concerned, the new floating exchange rate environment resulted in a depreciation of the dollar against major foreign currencies in 1973.

There is no doubt that international trade between the United States and the rest of the world was influenced by these new price relationships. However, it is difficult to say with certainty whether the 1973 swing from deficit to surplus resulted mainly from the reduction in the international price of the dollar. It is likely that a combination of other influences were instrumental in determining this turnaround in the trade balance.

Even though the U.S. economy had been in upswing for the three years through first quarter 1973, the rate of increase of U.S. imports declined in mid-1972. Imports of manufactured goods during 1973 increased only 2 percent in volume, compared to 13.5 percent in 1972 and 6.5 percent in 1971.7 This suggests that the dollar devaluation, which simultaneously reduced the foreign currency cost of U.S. exports and increased the dollar cost of imports, had a very strong effect in reducing U.S. demand for imports. ${ }^{8}$

The U.S. balance of payments for 1974 will be affected by many events. Since about 1966 U.S. domes-

\footnotetext{
TCouncil on International Economic Policy, International Economic Report of the President, $1974, \mathrm{p} .32$, and U.S. Department of Commerce, Overseas Business Reports.

8 In an analysis of U.S. trade performance in 1972, Wiliam Fellner suggested that in a period of cyclical apswing the ratio of the U.S. import growth rate to the export growth rate should increase in comparison to a previous time period (1964-1971). Since such an increase in the ratio was not observed, Fellner reasons that the reduction in the international price of the dollar exerted a strong influence during 1972. See Willian Fellner, "Controlled Fioating and the Confused Issue of Money Illusion," American Enterprise Instifute (February 1974).
}

tic production of petroleum has leveled off while U.S consumption has increased at a rapid rate (see chart entitled "United States Petroleum Supply and Demand"). The difference between domestic produotion and consumption has been made up by increased imports. In 1973, for example, U.S. consumption of petroleum was 17.3 million barrels per day (MBD) and imports amounted to $6.2 \mathrm{MBD}, 35.8$ percent of consumption.

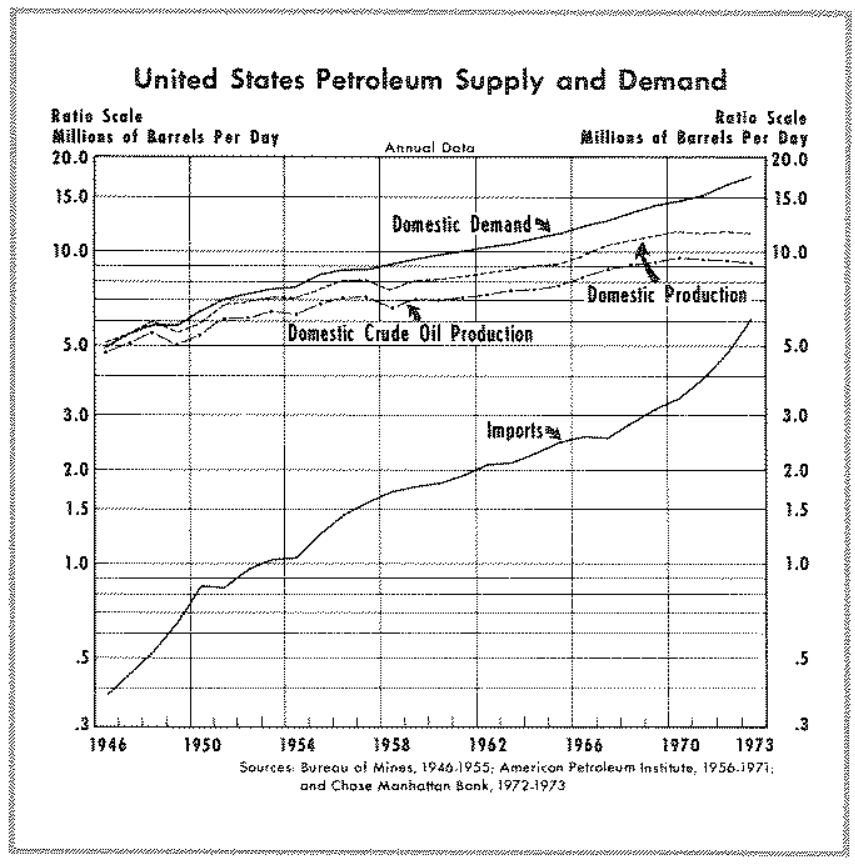

At the same time, prices of imported oil increased sharply. For example, the average price per barrel of imported oil was $\$ 2.75$ in January 1973 and climbed to $\$ 11$ in March 1974. U.S. expenditures for imports of petroleum and petroleum products climbed from $\$ 4.6$ billion in 1972 to $\$ 8$ billion in $1973^{\circ}$ Many projections for 1974 indicate that U.S. expenditures for ail imports will rise to about $\$ 25$ billion. ${ }^{10}$ This would imply a trade deficit for the United States in 1974, and indeed, preliminary first quarter trade data lend support to this conjecture.

Moreover, sharply increased expenditures for oil imports are projected for other industrial countries. The oil-exporting countries will therefore gain increased revenues, and these revenues will have to be disposed of one way or another. That is, they must either import more goods and services or invest their oil earnings in foreign assets.

"See Survey of Current Business (March 1974), p. 38.

10 See, for example, the International Economic Report of the President (March 1974), p. 107. 


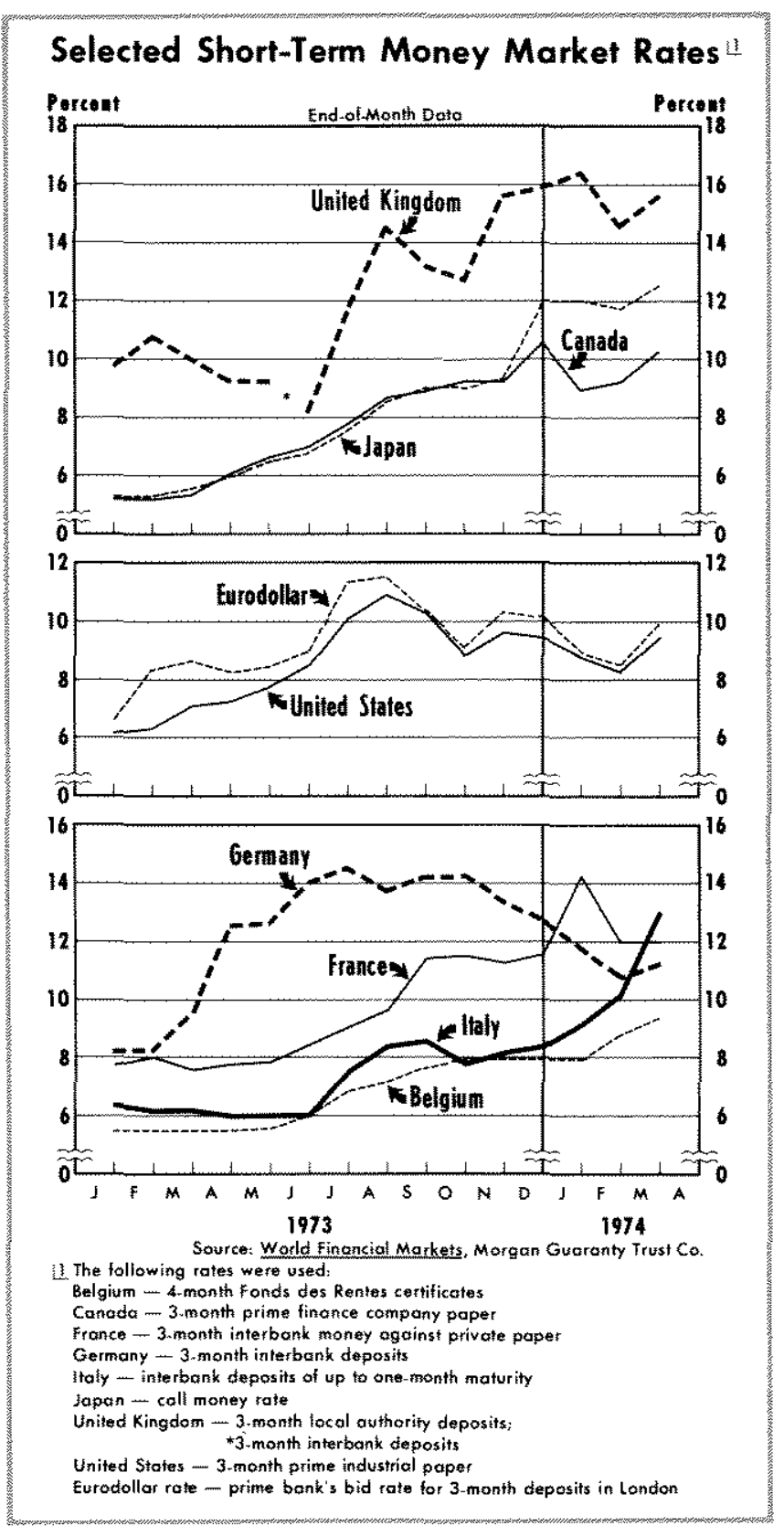

It is likely that oil-producing countries will not make completely offsetting purchases of imports from the industrial countries. Thus, oil-producing countries will seek investment opportunities in the industrialized countries. It is also likely that the flow of these investment funds to the United States will be greater than U.S. expenditures for oil imports. In this situation the U.S. trade balance may be in deficit, but the other intemational accounts of the United States may not be affected adversely.

Although U.S. short-term interest rates have increased since late February, the U.S. rates are still below those in most major foreign countries (see chart entitled "Selected Short-Term Money Market Rates"). If this differential is maintained, it may stimulate outHows of dollars into foreign money markets, thus leading to an increase in the quantity of dollars supplied. This would exert pressure toward a decline in the international price of the dollar.

Persistent acceleration of U.S. consumer price increases may be perceived by private international holders of dollar assets as an indication that the rate of inflation is likely to continue rather than to abate. Such anticipation may motivate an attempt to switchout of dollars into real assets. The recent surge in the price of gold would support this explanation.

On January 23 the United States suspended controls on foreign lending by U.S. financial institutions, and foreign investment by U.S. corporations. In addition, the Interest Equalization Tax was removed. This may again work toward future increases in the quantity of dollars supplied to foreign exchange markets. In short, although the dollar depreciation and emerging oil problems should increase the quantity of dollars demanded in international markets, differences in interest rates and rates of inflation, as well as the relaxation of U.S. capital controls may work toward an increase in dollars supplied to foreign markets.

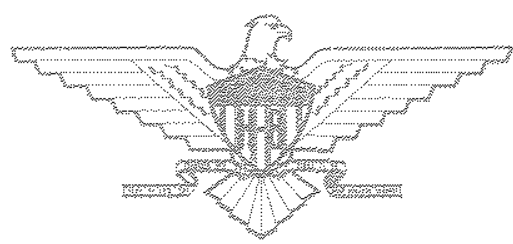

